\title{
Sangre de baguales. Epopeyas mapuches y obreras en tiempos del Complejo Maderero Panguipulli. Un efecto mariposa inconcluso*
}

\author{
Pedro Cardyn Degen
}

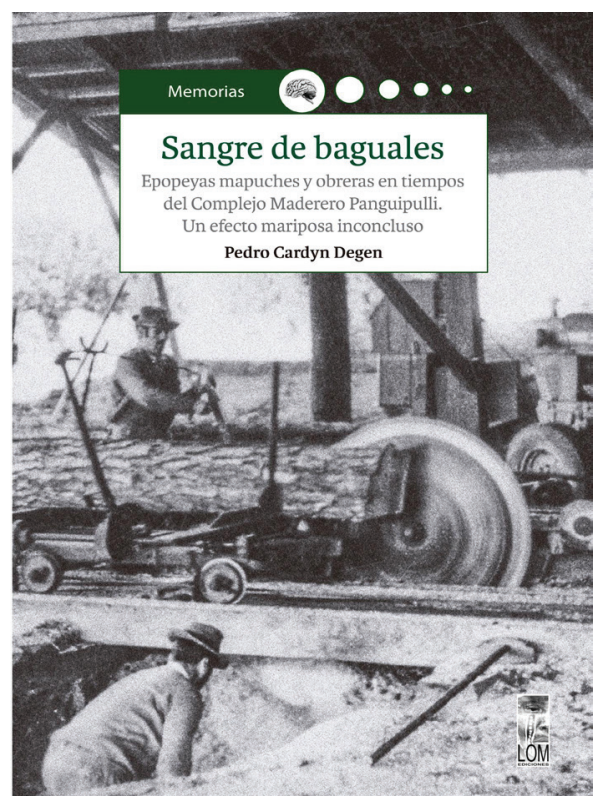

Roberto Morales-UrRA **

El autor nos convida a transitar, de la mano de una pequeña niña, desde los senderos de bosques y riberas de lagos hasta los pasillos de supermercados, construidos sobre la historia del traslado, por los caminos 
rurales, de campesinos y mapuche. Historias veraces e intencionadamente inexactas, siguiendo la lógica de la protección, de la clandestinidad, del relato insurgente, de la conspiración de las lluvias. Nutrido de actuales estudios y registros de prensa, como también de los relatos de cronistas de hace siglos, que se han instalado en la memoria convirtiendo las fantasías y descripciones castellanas en ancestros originarios, nos hace navegar por las vidas de mujeres en embarcaciones ya inexistentes.

Escribe un sobreviviente de la militancia partidista, vivida como secreto y luego como bandera desplegada, ahora como añoranza. A través de sus palabras reaparece el "compañero Pepe Liendo" y otros tantos que fueron estudiantes de la Universidad Austral de Chile en Valdivia. Algunos de esos nombres están grabados en un monolito levantado en los jardínes de la UACh como un póstumo homenaje, a iniciativa de unos de los fundadores del MIR en Valdivia, Juan C. García Vera.

Nos hace sentir la mística de la militancia en partidos políticos que se plantearon la revolución en los campos y ciudades, para construir el socialismo en Latinoamérica, en la senda del Che y otras y otros que lo precedieron... Nos invita a la peña de la sede Valdivia de la UTE, hoy campus Miraflores de la UACh. Nos damos cuenta que ha sido médico, en Futrono, en Valdivia, en Panguipulli, dialécticamente superado a sí mismo por la cultura de las abejas y la conciencia de la praxis ambiental. Nos transmite las angustiantes preguntas de un sobreviviente de frustrados intentos guerrilleros, en una especie de delirio, basado en ejercicios de política-ficción, imaginando un bosque de fusiles levantados por las manos de los trabajadores del Complejo Maderero y Forestal Panguipulli, liderando la resistencia rojinegra a la dictadura, cuyos ejércitos profesionales no disparan "balas locas" y sus tanques son de verdad. Nos cuenta del sentido de solidaridad y de la construcción cotidiana del bienestar común, valores y prácticas que hoy parecen utopías inalcanzables... como sería aquella de hacer una revolución.

El miedo es un acompañante insistente, tenaz, impredecible... hasta estos días, y eso explicaría en parte el alcoholismo y la adhesión al evangelismo, y también el acto increíble del asesinato entre compañeros, como el soportar y resistir por meses la ocupación militar, desde el Golpe de septiembre de 1973.

Pero también nos habla de las rabias y del miedo que provocaron los avances en la organización del poder popular y la formación del 
Complejo, en los opositores al gobierno de Allende. Todo ese miedo que transmitieron por su prensa, por sus radios, en los colegios de su propiedad e influencia.

Es que las injusticias cometidas por décadas por empresarios y latifundistas en contra de las clases obrera y campesina, y por siglos en contra del pueblo mapuche, las represiones y asesinatos que perpretaron para intentar impedir los avances de las luchas sociales, aunque las ocultaban o las justificaban como legítimas medidas para mantener e imponer su paz social y su unidad nacional, quedaron en las memorias individuales y colectivas de todos.

Así asesinaron en 1907 a las familias obreras en la Escuela Santa María en lquique, el mismo año en que se habían reunido en enero los pulonko mapuche en Coz Coz para acordar la manera de reclamar por los asesinatos y abusos en toda la zona mapuche-williche-pewenchelafkenche-puelche1. Así siguieron asesinando en los desalojos a familias mapuche en Forrawe en 1912, a los campesinos chilenos y mapuche de Ranquil en 1934, a los obreros madereros de Neltume en $1951 \ldots$

Los asesinatos, despojos, fraudes y engaños marcaron a fuego las relaciones humanas. Se asustaron con Recabarren y su legado, con Marmaduque Grove, con el gobierno de Pedro Aguirre Cerda. En los territorios del centro-sur-austral poco a poco avanzaban los regidores, alcaldes, diputados y senadores socialistas y comunistas. Decaían los radicales y surgía la "tercera vía" entre capitalismo y socialismo, la socialdemocracia de la DC.

¡Por supuesto que vivieron como amenaza permanente el triunfo de la Unidad Popular! Mientras por la radio sonaban los encendidos discursos de los representantes populares y líderes de la UP, se aplicaban las 40 medidas del Programa que hizo que el cobre por primera vez fuera $100 \%$ de los chilenos, se profundizó la Reforma Agraria, se fortalecieron los sindicatos de obreros y se mejoró la vida del campesinado, se validó y respaldó el sistema comunitario de los pueblos indígenas. Todo eso se sobredimensionaba por la propaganda del gobierno y sus adherentes, a quienes la derecha y la DC llamaron con desprecio de clase como "upelientos", y por las consignas de los que querían "avanzar sin transar", "no nos trancarán el paso", se les tachaban de "extremistas". 
Se dieron muchas batallas en esta lucha: la de la producción, la de la cultura, la de las artes, la de la alfabetización, la de la recuperación de tierras mapuche, la de los medios de comunicación: en la prensa escrita y en las radios que estaban más parejamente distribuidas, aunque las de alcance nacional eran en su mayoría del empresariado que se opuso tenaz y dogmáticamente a las reformas del proceso revolucionario chileno. Entre el Punto Final y El Correo de Valdivia la pugna de ideas e imágenes era sin cuartel, aunque tuvieron coincidencias en criticar incansablemente a la UP, unos por reformista y los otros por querer imponer una dictadura comunista.

Unos hicieron propaganda política con los estudiantes universitarios, que apoyaban a los trabajadores una vez que se formó el Complejo Neltume, destacándolos como líderes, haciéndo aparecer como dirigente campesino a Gregorio Liendo; a quien los otros lo sindicaban como "Comandante Pepe"; aprovechando el izquierdismo discursivo, continuaban con la campaña del terror que habían iniciado desde siempre, y que ya la habían aplicado con éxito en contra de Allende cuando fue derrotado por Frei, con el apoyo del gobierno de los EUA y la socialdemocracia europea.

Luego, el exilio obligado para salvar las vidas, y aquel interno para subsistir.

Como toda historia contada desde el corazón, en estos relatos el autor nos reitera y destaca la militancia mirista, para él significativa, como lo fue para algunos mapuche, chilenos y gringos. Tanta emoción, y a veces la sobreideologización, dificultan el dar profundidad histórica a algunos hechos, dando la impresión que si no fuese por ellos los trabajadores de los aserraderos no se habrían organizado y los mapuches no habrían reclamado sus tierras. Pareciera que solo en ese período se hacían conocidas sus demandas y sus luchas; pero ya en 1907 se publicaba, por sacerdotes alemanes y periodistas chilenos, un registro de las luchas mapuche y ya habían células del partido comunista en los años 20, para el terror de capuchinos, jueces, latifundistas y empresarios. Los obreros y campesinos chilenos, y los mapuches que sabían leer y escribir, eligieron en votaciones a regidores y alcaldes de los partidos populares de la época: comunistas, socialistas, radicales.

Ya habían sido perseguidos... como el mismo autor nos recuerda, al narrar lo sucedido con la persecusión política a Pablo Neruda por Gabriel 
González Videla, con su Ley de Defensa Permanente de la Democracia, la "Ley Maldita", y que verificamos en la nómina de decenas de miles de comunistas proscritos en "El Peligro Rojo"2.

Lo que el sobreviviente pretende con su sobrina, al publicar estos relatos, es dar continuidad a los procesos históricos, visibilizar lo sucedido, lo que ya pasó, para aquellos que construyen lo que será el pasado de las nuevas generaciones; pero no recorre todos los puentes para encontrarse con los antepasados de la lucha social y política... ¡Gran dilema! o ¿profunda contradicción? Como aquella que nos relata del sacerdote francés que se volvió "comunista" a los ojos de sus feligreses latifundistas, por celebrar misa en Navidad para las familias que habían ocupado un fundo en Futrono. O la de quién se inmola al intentar salvar de un incendio a jóvenes de catequesis, como lo hace años después Sebastián Acevedo por sus hijos asesinados por la dictadura, con cuyo nombre el jesuita José Aldunate bautiza al movimiento contra la tortura, guerrileros de la no violencia activa en las ciudades de Chile en los 80 .

Sacar una pistola y no seguir sacándose el sombrero ante el patrón, es lo que pregonaban algunos estudiantes universitarios y, paradojalmente, reproducían las relaciones de dominación, a través de un paternalismo patriarcal con sus afanes de ser la vanguardia de un proceso mayor, construido y fundado por otros. Ya antes de la Unidad Popular en Chile y de la Revolución en Cuba, se vivieron tales contradicciones y dilemas, en los procesos de liberación nacional en distintos estados africanos para sacarse de encima años de dominio colonial europeo, no por pequeños grupos de estudiantes, sino por pueblos enteros que en sus prácticas llevaban dentro al colonizador.

Físicamente ya no estaban los patrones, pero seguían presentes y era una gran tarea romper esa relación de dependencia y dominación. No se trataba de cambiar al patrón latifundista por el papá estado o el compañero vanguardia. El compañero Presidente Allende lo tenía muy claro... y seguramente algunos de los campesinos y obreros mapuche y chilenos recordarán lo que dijo en su discurso de octubre de 1972 en el Coliseo de Valdivia:

El Estado no es un patrón ni trabaja la tierra... Oíganlo bien: El Estado no reemplaza al antigüo patrón, el propio patrón es el trabajador; él, la comunidad, el asentamiento, todos 
en conjunto son los que tienen la posibilidad de adjudicar sus ingresos, de acuerdo con lo que produzcan, y la productividad de cada cual ${ }^{3}$.

Lo que podría explicar en parte la casi ausencia de resistencia física y menos militar al golpe, al asalto cotidiano, a la exoneración de los trabajadores, a la expulsión, a las vejaciones en privado y a las humillaciones públicas, buscando el control de los cuerpos pensantes y dolientes.

Pedro nos muestra los horrores de la dictadura, que se instala como una manera de administrar, de gobernar, de vivir. La cultura del terror institucionalizada. Nos presenta su temprana sintonía con el pueblo mapuche, intuitiva al comienzo en su rol como médico, acompañado de las indicaciones de una conversación sostenida con otro médico -letón, judío y comunista-, quién decía a quién lo quisiera escuchar y leer, que había que luchar por la comunidad, que había que construir repúblicas indígenas autónomas y federadas. Eso decía Alejandro Lipschutz... pocos lo escucharon, aunque hoy la resonancia de sus palabras se adivinan en las luchas actuales ${ }^{4}$.

Pedro nos cuenta de su apoyo a la huelga de hambre de varios mapuche, en la Plaza de la República en Valdivia, para conseguir la libertad de un lonko. Nos confidencia de su promoción de las recuperaciones de tierras mapuche y nos guiña su nueva familia mapuche. Las experiencias vividas le hacen hoy superar la visión binaria de lo bueno y lo malo, pudiendo encontrarse con personas que fueron sus adversarios políticos del período y tender los puentes al diálogo, ampliando la perspectiva, así como ha sucedido con un antiguo dirigente campesino democristiano, quizás por el denominador común de los valores de solidaridad y justicia que el cristianismo proclama, más que por lo democráticas que puedan ser sus prácticas.

Y, sin embargo, mantiene las diferencias de lo que fue y pudo haber sido el proceso revolucionario allendista, mientras se integraba al intento de guerrilla a inicios de los 80 , volviendo al territorio del Complejo, concidiendo en que todas las formas de lucha son válidas para acabar con el dominio dictatorial. Como cuando "El Pelao" Krauss, uno de los

Allende, Salvador. 1972 "La política agraria del gobierno de la U.P. Valdivia el 7 de octubre de 1972" R.R.P.P. - CORA.

4 Ver Morales, R. 2005 "El legado teórico a la antropología acerca de los Pueblos Originarios en Chile" (402-411), en Alejandro Lipschutz. Nueva Antología. CNCA- ICAL. 
fundadores del MIR en Valdivia, al momento de ser llevado a fusilamiento en la cárcel en la Isla Teja en Valdivia, entona el himno símbolo: "La Internacional"... Finalmente, hermanados por la muerte... la vida y la esperanza. 
